\title{
On Starfish Island: the Philippine Group of Law Librarians Seminar of April 2008
}

The Philippine Group of Law Librarians (PGLL) held its Seminar on 'Partnering for Successful Library and Information Services' at the Asturias Hotel in Puerto Princesa City on Palawan Island from 21 to 23 April 2008. It constituted a three-day conference with a full academic programme and also a busy schedule of social and cultural events. This conference was part of a long tradition of well-attended professional events organised by this extremely active association. I will take the opportunity to describe the professional context as well as the conference programme. I will try not to linger too long over the delights that the Philippines offer to the traveller but I will get to Starfish Island.

I was very fortunate to be invited, as President of the International Association of Law Libraries (IALL), to be a guest of the PGLL and a speaker at their 2008 conference. The IALL has in a modest way encouraged and supported the PGLL over the past few years. In 2006 the Vice-President of the PGLL, Lilia Echiverri received a professional development bursary from the International Association to attend the $25^{\text {th }}$ IALL Annual Course in International Law Librarianship at the Faculty of Laws of St. Petersburg State University. In October of the following year, Professor Dr. Holger Knudsen, former President of the IALL, attended a PGLL conference and had the honour of presiding over the investiture of the new officers of the Group.

\section{IALL and the PGLL}

Looking back over the records of the IALL, the growing relationship created by these recent contacts is not the first time the two associations have worked together. IALL played a small part in the foundation of the PGLL some years ago. The IALL has worked closely with the International Federation of Library Associations for many years, organising law programmes at their General Conference for librarians concerned with legal information who could not attend a specialist law library conference. In 1980 the General Conference of IFLA took place in Manila, described as the 'first such conference to be held in a developing country". ${ }^{1}$ IALL organised an 'IALL week in Manila' attracting about forty law librarians, thanks to the work of a very successful local coordinating group. In particular IALL sponsored a Round Table to discuss 'Collection Development and Documentation of Human Rights' which was attended by seventeen Filipino librarians and eighteen other librarians from Australia, Canada, Japan, Malaysia, Nigeria, Thailand and the United States.

The events evidently gave 'a good stimulus to further development of law librarianship in the region'. The evidence is the spontaneous establishment of a 'Philippine law library association' at the proposal of Dean Froilan M Bacuñgan of the University of the Philippines College of Law speaking at the Round Table. Originally conceived as an IALL local chapter (in common with several other new national law library associations), it came into being as a national and incorporated association, the PGLL. The articles of incorporation which appear at the foot of the 2001 by-laws of the PGLL are dated March $1981^{2}$ and the incorporation was approved by Securities and Exchange Commission on 21 August 1981. The first President of the PGLL, Professor Myrna S Feliciano of the University of the Philippines Law Center, was a member of the Board of Directors of IALL from 1977-1983. 


\section{Philippine Librarians Association}

Lilia Echiverri, Vice-President of PGLL and Librarian of the University of the Philippines Law Library, has recently been elected as President of the Philippine Librarians Association Inc. (PLAI), taking up office in December 2008. The PLAl is the nationally accredited association in the Philippines and is a partner in regulating the profession. It is the oldest such organisation in Asia and became a member of IFLA in 1929. The PLAI is the umbrella group for several associations of librarians by sector or specialisation and has been at the forefront of a long struggle for state recognition of librarianship as a profession. The University of the Philippines, a state university, started courses in library science in 1914 and the PLAI itself was founded in 1923 as the Philippine Libraries Association. Official recognition of the profession of librarianship came in 1990 with the Philippine Librarianship Act. ${ }^{3}$ The regime for regulating the profession and licensing practitioners has been revised by the Philippine Librarianship Act $2003^{4}$ and the PGLL sponsored a Round Table discussion on the new regime in February 2007 at the library of the University of the Philippines College of Law. ${ }^{5}$

\section{Philippine Group of Law Librarians}

The PGLL ${ }^{6}$ is affiliated to the PLAl and works closely with it; they are both based at the National Library. The PGLL has nearly 300 members $^{7}$, a little under a quarter from educational institutions (colleges, universities), another quarter from government and legislative libraries (including the Senate Legislative Library, the House of Representatives Congressional Library, the Office of the President, city and provincial prosecutors' offices, and various government departments, commissions and national enterprises), about 16\% from court libraries (Regional Trial Court Libraries and the Supreme Court Library), about 13\% from private law offices and legal offices of companies mostly based in Makati City, the business district of the capital, Manila. Membership of the Group is by individual law librarians rather than by law libraries since it is the individual librarian who is regulated through professional accreditation (I have seen librarians give the number of their license to practise on some documentation).

The PGLL has developed to become a cohesive force to unite law librarians and raise the standards of law librarianship in the country. It serves as an instrument for the advancement of legal documentation and scholarship and the furtherance of research in the field of law; it provides a forum for the consideration and analysis of problems and issues affecting the practice of law librarianship. Since its establishment, informal inter-library cooperation has evolved and a strong nationwide network has been established. A publication program has been pursued with a PGLL Newsletter and the Philippine Journal of Law Librarians ${ }^{8}$ being issued; other publications such as "A Union List of Legal Periodicals of Metro Manila Law Libraries," April 1986 and "Union List of Human Rights Resources in the Philippines" (for the Commission of Human Rights) have been produced.

The PGLL has made a considerable contribution to the development of the competencies and skills of its members with PGLL-sponsored conferences, seminars, forums and dialogues. One such activity, the 'Round Table Discussion on Formal Education for Law Librarians' held on 18 August 1989 led to the establishment by the University of the Philippines Institute of Library and Information Science of a Diploma in Law Librarianship programme. The PGLL often arranges 
events in association with the PLAl and with the Philippine Association of Academic and Research Librarians (PAARL). The PGLL also contributed significantly to the crafting, passage and dissemination of the general laws regulating the profession of librarianship noted above.

\section{Manila}

I arrived in Manila and, although I had only a day before flying on to the venue for the conference on Palawan Island, I was very kindly taken on a whirlwind tour of the capital city. This included the thriving business district of Makati City where the large law firms are located, the beautiful waterfront, and the Rizal Park commemorating Dr José Rizal, a scholar who laid the early groundwork for independence in the late nineteenth century and was executed in 1896. We also saw some of the architectural remains of Spanish colonial rule which extended from 1521 to 1898 (to be followed almost directly by a period of governance by the United States until independence was achieved in 1946). We toured the Intramuros district of the city which, as the name suggests, is the area within the old city walls which formed the heart of Spanish government, church and society during the colonial period. The San Agustin church was completed in 1607 and is probably the oldest surviving building in the Philippines, although the earliest church on the site evidently dates back to 1571 and this itself was a surprise to me because I had not imagined a permanent Spanish presence in the islands at that early date.

\section{Palawan}

The next day, a Sunday, we flew to Palawan Island; much of the internal travel in the Philippines is by air. Palawan Island is the third largest of over 7,000 which make up the complex Philippines archipelago; the Island is 280 miles long but only about 30 miles across and runs from the south-west near Borneo in a northeasterly direction towards the centre of the Phlippines. The Island and nearby smaller islands make up Palawan Province and the provincial capital is Puerto Princesa City. The island is mostly undeveloped with a rural economy based on fishing and the production of coconut, rice, corn, and cashews. The Island has a long irregular coastline of rocky coves and white sandy beaches with a multitude of tiny islands close offshore. Apart from narrow coastal plains, there are very large stretches of dense forest covering the central mountain ranges. The Island is quite remarkably beautiful.

\section{Academic Programme}

The Seminar was entitled "Partnering for Successful Library and Information Services" and the objectives for the participants were: to be updated on the new trends in librarianship; gain awareness of what, how and why partnering is important to library and information services; know the issues and problems of partnerships; and to jump start partnering among the participants.

The seminar was open to all librarians, library administrators, library support staff, information specialists, knowledge managers, researchers / associates, and friends and stakeholders of library and information services who wanted to learn about partnering, networking and resource sharing from international libraries and librarians' experience and perspective. Overall over 60 people participated in the Seminar, mostly from across the Philippines, reflecting the diversity of membership of the Group by sector, but delegates and speakers also came from Indonesia, Malaysia, Singapore, Thailand, and of course the United Kingdom. The conference 
attracted some university library staff whose specialism is not law librarianship but who were interested in the general topic.

The main talks were each about an hour in length:

- Libraries and Librarians of the Future: an international perspective by Jules Winterton covering the impact of globalisation on factors affecting law librarianship including the proliferation of legal systems, legal education and the practice of law, information needs, publishing and mass digitisation, and international standards. The talk also covered the contrary trends towards small, local and low-cost solutions.

-Partnering and Resource Sharing: Malaysian experience and prospects among Asian libraries by Harvinder Kaur. Her talk described existing and developing networks and ways to share expertise and knowledge. Harvinder Kaur, formerly of the University of Malaya Law Library now of the US Embassy Resource Center in Kuala Lumpur, played a leading role in establishing the Law Librarians Group of Malaysia $^{9}$ and was an IALL scholarship holder in 2005 at the IALL conference at the European University Institute in Fiesole.

-Legal Information on the Web: can we trust the official version? by Jules Winterton. This presentation described the free-to-Internet publication of primary legal materials by government and other agencies and the development of standards for accessibility, comprehensiveness, reliability, official status, authenticity and preservation for permanent public access and the adoption in the USA of 'Core Values Concerning Public Information of Government Websites' as guidelines to best practice.

-Building Synergy with Stakeholders: clientele-librarian relationships by Milagros Santos-Ong, Director of Library Services at the Supreme Court of the Philippines. The talk gave concrete examples of the development of online web-based services at the Supreme Court Library and elsewhere which not only make services more relevant and responsive to the clientele but also contribute towards the general availability of legal information in the Philippines. The development of the Supreme Court e-Library ${ }^{10}$ has been accompanied by research into unpublished Supreme Court decisions and gaps in published decisions are being filled by online publication. Milagros Santos-Ong was awarded the Outstanding Professional Librarian of the Year in 2005 by the Professional Regulation Commission for this work. She is also the author of a detailed online guide, Philippine Legal Research ${ }^{11}$ which is the best starting point for work on Philippine legal materials.

- Power of Partnership: a visionary view by Professor Sujin Butsiduwan, Dean of the Faculty of Informatics at Mahasarakham University in Thailand. Dr. Sujin's paper discussed the 'power of partnership' as part of the spirit of professionalism, as a fundamental role, and as a contribution in many dimensions and activities to meeting needs, building intellectual assets and developing expertise in the science of librarianship. His talk covered resource sharing and cooperation, the professional dilemmas of serving one's own clientele and helping others, and some common ways of sharing resources that both improve services to one's clientele and help others. His paper also illustrated how today's Internet / Web environment positively enables and affects cooperation. 
-Issues and Problems in Partnership by Dr. Lilia R. Austriaco, Professor and Dean, College of Engineering, Angeles University, Angeles City in the Philippines and former Manager of the Information Resources Centers at the Asian Institute of Technology in Thailand concentrated on practical issues relating to partnerships including financial and institutional policy issues.

Each talk was followed by an open forum of up to half an hour which comprised lively interventions, discussions and exchanges of information about the Philippine context. It is clear that there is a great deal of informal networking and a great enthusiasm for collaboration and that the PGL serves a very important purpose in bringing together professionals for practical cooperation as well as to share transferable professional skills. It is also clear that law librarians in the Philippines are making an increasing contribution to the availability of legal information, empowered by the ability to publish on the Internet.

There were also market update sessions including presentations by representatives of $C$ \& $E$ Publishing Inc of the Philippines, publishers and distributors of foreign books, by Westlaw (ASEAN Region), and by LPI Group on their range of library equipment and racking systems.

\section{Starfish Island}

Prior to the start of the conference, after arrival on Palawan Island on Sunday, delegates left by coach for a trip to Honda Bay, about ten kilometres from Puerto Princesa City. This is one of the most gloriously beautiful white sandy beaches I have ever seen. It was also the site of the abduction of tourists from a resort by a militant Islamic group in May 2001. However, the security situation has improved considerably since then and no other similar incidents have occurred. The point of the excursion was not Honda Bay beach itself, although that would have been worth travelling across the world to see but rather 'island hopping' by small powered outrigger canoes. We waded ashore at three small islands and had lunch by the simple expedient of putting seafood into a boiling pot of water over a brazier. The final island was Starfish Island and the fringe of the sea was indeed littered with hundreds of starfish. These were not like starfish I have ever seen, they were large, heavy and inflexible and might almost have been made from concrete, although I doubt the tourist authorities had put them there to decorate the island.

\section{Underground River}

The excursion following the conference, for those who could stay on the Wednesday afternoon, was described as an 'Underground River Adventure' and so it proved. The Puerto Princesa Subterranean River National Park ${ }^{12}$ is a UNESCO World Heritage Site and one of the most important conservation areas in the Philippines. The underground river runs through a spectacular limestone cave system which extends for more than 20 kilometres under the mountains. The river is navigable for over 8 kilometres and is widely regarded as the longest navigable underground river in the world. It emerges at the foot of a high cliff directly into a small tidal lagoon open to the South China Sea. The lagoon is set within lush tropical rainforest which runs right down to the beach. 
The site is about 50 kilometres from Puerto Princesa under the St Paul mountain range and the river itself is known as the St Paul River. We reached the lagoon by a short boat ride from a beach roadhead and a - admittedly very short - walk along a path in the forest passing several very large but stationary monitor lizards. Equipped with lifejackets and hard hats, we were taken in small boats of 6 or 8 people paddled by hand along part of the river - the further reaches are closed to tourists to protect the environment. The cave system and the forest above are important habitats for a great variety of flora and fauna. A half hour professional documentary film ${ }^{13}$ was shown at the entrance to the Park prior to the river trip although I wish I had not seen the part about the particularly aggressive species of spider which inhabits the caves. As one drifts silently along looking in torchlight at the strange rock formations, swallows which live and nest deep in the caves flit past the heads of you and your fellow travellers in the darkness emitting their 'echo-location' cries. A fascinating, rather eerie, but companionable experience.

\section{Certificate of Appreciation}

The conference ended with a ceremony to present attendance certificates and certificates of appreciation and gifts to the speakers. My certificate now has a prominent place on the wall of my office as a memento of the experience. I would like to thank all the officers of the PGLL ${ }^{14}$ and my fellow participants in the Seminar for their unfailing hospitality and generosity towards a large foreigner and for their tremendous enthusiasm for their chosen profession which is refreshing and reinvigorating! I would like to thank the law firm ACCRALAW for their sponsorship of part of my stay. I would also like to thank Lilia Echiverri in particular for her kind assistance and mentoring throughout my visit. I hope to return to the Philippines and perhaps even return to Starfish Island!

by Jules Winterton, Associate Director and Librarian at the Institute of Advanced Legal Studies (IALS), University of London and President of the International Association of Law Libraries (IALL).

\footnotetext{
1 'IALL Week in Manila' by Adolf Sprudzs, 8 International Journal of Law Libraries 193 (1980)

2 http://www.geocities.com/pgllboard/blaws.htm

3 Republic Act no.6966, "Act regulating the practice of librarianship and prescribing the qualifications of Librarians". The regime is described in paper 134-E to the $69^{\text {th }}$ IFLA General Conference 2003 in Berlin, 'The professionalization of librarians in the Philippines: the role of library associations' by Antonio M Santos at http://www. ifla.org//V/ifla69/papers/134e-Santos.pdf

${ }^{4}$ Republic Act no.9246

${ }^{5}$ SLiS Newsletter - School of Library and Information Studies, University of the Philippines, Jan-Mar 2007, p.2

${ }^{6}$ The PGLL's website http://www.geocities.com/pgllboard/index.htm is a little out of date at the moment

${ }^{7}$ The membership directory at http://www.geocities.com/pgllboard/members.htm is dated 2005 and it is from this that the analysis by sector of membership is derived. The total membership figure is up to date.

${ }^{8}$ ISSN 0117-0872. Four volumes appear to have been published so far, in 1990, 1991, 1992, and 2001.

9 http://www.lib.uum.edu.my/LLG/LawGroup.htm

${ }^{10}$ The Supreme Court e-Library is at http://elibrary.judiciary.gov.ph/ and although mainly designed for the operation of the Court, parts are generally available; it has recent Opinions, Court Rules, Circulars and Orders back to 1973, as well as a copy of the 1987 Constitution and a list of licensed Philippine attorneys. The Chan Robles law firm has a virtual law library which is publicly available from http://www.chanrobles.com/ with an impressive selection of Philippine laws and Supreme Court opinions back to 1901.
} 
${ }^{11} \mathrm{http}: / / \mathrm{www}$. nyulawglobal.org/globalex/philippines1.htm latest version December 2007

12 http://www.puerto-undergroundriver.com/

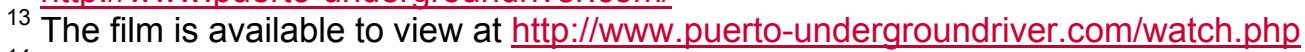

${ }^{14}$ The officers of the PGLL for 2007-09 are: President, Emma M. Rey of the Congressional Library Bureau (House of Representatives); Vice-President, Lilia F. Echiverri, University of the Philippines Law Library; Secretary, Corazon G. Tolentino, Senate of the Philippines Library; Treasurer, Sally C. Tuason, Jose Rizal University Library; Auditor, Nora P. Rey, Villaraza \& Angangco Law Offices Library; Public Relations Officer, Nancy T. Tuason, Legislative Library Service (House of Representatives. The Directors are: Julia M. Romano, Office of the Govt. Corporate Counsel Library; Maria B. Tubid, Ombudsman Library; Margie C. Rogan, ACCRA Law Office Library; and Ex-Officio, Helen C. De Castro, Presidential Management Staff Library. 